Cellular Physiology
and Biochemistry and Biochemistry Published online: June 19,2018

Accepted: April 20, 2018

This article is licensed under the Creative Commons Attribution-NonCommercial-NoDerivatives 4.0 International License (CC BY-NC-ND) (http://www.karger.com/Services/OpenAccessLicense). Usage and distribution for commercial purposes as well as any distribution of modified material requires written permission.

\title{
Stimulation of Eryptosis by Afatinib
}

\author{
Abdulla Al Mamun Bhuyan ${ }^{a}$ Florian Lang ${ }^{b, c}$
}

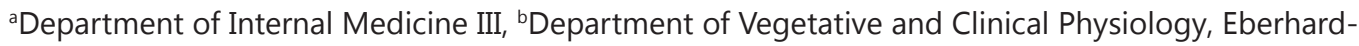
Karls-University of Tuebingen, Tuebingen, 'Department of Molecular Medicine II, Medical Faculty, Heinrich Heine University, Düsseldorf, Germany

\section{Key Words}

Afatinib • Eryptosis $•$ Phosphatidylserine $\cdot$ Calcium $•$ Oxidative stress $\bullet$ Ceramide

\begin{abstract}
Background/Aims: The epidermal growth factor receptor (EGFR) tyrosine kinase inhibitor afatinib is primarily utilized for the treatment of non-small cell lung carcinoma. The drug is at least partially effective by triggering suicidal tumor cell death. Side effects of afatinib treatment include anemia. At least in theory, afatinib induced anemia could be secondary to stimulation of suicidal erythrocyte death or eryptosis, characterized by cell shrinkage and cell membrane scrambling with phosphatidylserine translocation to the erythrocyte surface. Signaling potentially stimulating eryptosis include increase of cytosolic $\mathrm{Ca}^{2+}$ activity $\left(\left[\mathrm{Ca}^{2+}\right]_{\mathrm{i}}\right)$, induction of oxidative stress, and increase of ceramide abundance. The present study explored, whether afatinib induces eryptosis and, if so, whether its effect involves $\mathrm{Ca}^{2+}$ entry, oxidative stress, and/or ceramide. Methods: Flow cytometry was employed to quantify phosphatidylserine exposure at the cell surface from annexin-V-binding, cell volume from forward scatter, $\left[\mathrm{Ca}^{2+}\right]$ from Fluo3-fluorescence, reactive oxygen species (ROS) abundance from DCFDA dependent fluorescence, and ceramide abundance utilizing specific antibodies. Results: A 48 hours exposure of human erythrocytes to afatinib $(\geq 4 \mu \mathrm{g} / \mathrm{ml}$ ) significantly increased the percentage of annexin-V-binding cells and significantly decreased forward scatter. Afatinib significantly increased Fluo3-fluorescence, DCFDA fluorescence and ceramide abundance. The effect of afatinib on annexin-V-binding and forward scatter was significantly blunted by removal of extracellular $\mathrm{Ca}^{2+}$. Conclusions: Afatinib triggers phospholipid scrambling of the erythrocyte cell membrane, an effect at least in part due to $\mathrm{Ca}^{2+}$ entry, oxidative stress, and ceramide.
\end{abstract}

(C) 2018 The Author(s)

Published by S. Karger AG, Basel

\section{Introduction}

Afatinib, a second generation epidermal growth factor receptor (EGFR) tyrosine kinase inhibitor [1-17], is primarily utilized for the treatment of non small cell lung carcinoma [1, $3,5,7,9-14,16-40]$. Side effects of afatinib include skin rash [6], xerosis [6], paronchia [6], stomatitis [6,41], diarrhea [6, 41], heart failure [42], neutropenia [41], leukopenia [41], 
and anemia [41, 43]. Afatinib is in part effective by inducing apoptosis [44-57], an effect involving oxidative stress [46].

At least in theory, the anemia following afatinib treatment could be secondary to suicidal death of erythrocytes or eryptosis [58-60]. Hallmarks of eryptosis are cell shrinkage [61] and cell membrane scrambling with phosphatidylserine translocation to the cell surface [58]. Cellular mechanisms participating in the orchestration of eryptosis include increase of cytosolic $\mathrm{Ca}^{2+}$ activity $\left(\left[\mathrm{Ca}^{2+}\right]_{\mathrm{i}}\right)[58]$, ceramide [62], caspases [58, 63, 64], G-protein Galphai2 [65], casein kinase $1 \alpha$ [58], Janus-activated kinase JAK3 [58], protein kinase C [58], and p38 kinase [58]. Eryptosis is suppressed by AMP activated kinase AMPK [58], cGMP-dependent protein kinase [58], mitogen and stress activated kinase MSK1/2 [66], PAK2 kinase [58] and sorafenib/sunitinib sensitive kinases [58]. Eryptosis could be triggered by cell stress, such as hyperosmotic shock [58], oxidative stress [58], energy depletion [58], radiation [67, 68], or exposure to a wide variety of substances [58, 66, 69-112]. Several substances inhibit eryptosis [113-116]. Enhanced eryptosis is observed in diverse clinical conditions including iron deficiency [58], vitamin D excess [117], chronic kidney disease (CKD) [118-123], hemolytic-uremic syndrome [124], autoimmune hemolytic anemia [125], diabetes [126], hypertension and dyslipidemia [127], hepatic failure [128], malignancy [129-131], arteritis [132], systemic lupus erythematosus [133], sepsis [134, 135], malaria [58, 136, 137], sicklecell disease [58], beta-thalassemia [58], Hb-C and G6PD-deficiency [58], Wilsons disease [134], as well as advanced age [138]. Eryptosis further increases following storage for transfusion $[67,68,83,139]$ and is enhanced in erythrocytes from newborns exposed to oxidative stress $[58,140]$.

The present study explored, whether exposure of erythrocytes drawn from healthy volunteers to afatinib influences cell membrane scrambling and cell volume. Additional experiments were performed to shed light on the signaling involved.

\section{Materials and Methods}

\section{Erythrocytes, solutions and chemicals}

Fresh Li-Heparin-anticoagulated blood samples were kindly provided by the blood bank of the University of Tübingen. The study is approved by the ethics committee of the University of Tübingen (184/2003 V). The blood was centrifuged at $120 \mathrm{~g}$ for $20 \mathrm{~min}$ at $21{ }^{\circ} \mathrm{C}$ and the platelets and leukocytes-containing supernatant was disposed. Erythrocytes were incubated in vitro at a hematocrit of $0.4 \%$ in Ringer solution containing (in mM) $125 \mathrm{NaCl}, 5 \mathrm{KCl}, 1 \mathrm{MgSO}_{4^{\prime}}$ $32 \mathrm{~N}$-2-hydroxyethylpiperazine-N-2-ethanesulfonic acid (HEPES; pH 7.4), 5 glucose, $1 \mathrm{CaCl}_{2}$, at $37^{\circ} \mathrm{C}$ for 48 hours. Where indicated, erythrocytes were exposed for 48 hours to afatinib (MedChem Express, Princeton, USA). In order to estimate the impact of $\mathrm{Ca}^{2+}$ entry on afatinib induced phosphatidylserine exposure, ROS and ceramide formation, erythrocytes were exposed to afatinib in the absence and presence of extracellular $\mathrm{Ca}^{2+}$. To explore the participation of Akt/ PKB signaling pathway, erythrocytes were exposed for 48 hours to a combination of afatinib and Akt1/2 kinase inhibitor A6730 (58nM) (Sigma Aldrich Germany),

\section{Annexin-V-binding and forward scatter}

After incubation under the respective experimental condition, a $150 \mu \mathrm{l}$ cell suspension was washed in Ringer solution containing $5 \mathrm{mM} \mathrm{CaCl}_{2}$, stained with Annexin-V-FITC 1 1:200 dilution; ImmunoTools, Friesoythe, Germany) and incubated at $37^{\circ} \mathrm{C}$ for 15 min under protection from light. The annexin-V-abundance at the erythrocyte surface was subsequently determined on a FACS Calibur (BD, Heidelberg, Germany) [141]. Annexin-V-binding was measured with an excitation wavelength of $488 \mathrm{~nm}$ and an emission wavelength of $530 \mathrm{~nm}$. A marker (M1) was placed to set an arbitrary threshold between annexin-V-binding cells and control cells. The same threshold was used for untreated and afatinib treated erythrocytes. A dot plot of forward scatter (FSC) vs. side scatter (SSC) was set to linear scale for both parameters. The threshold of forward scatter was set at the default value of " 52 ".

\section{KARGER}


Intracellular $\mathrm{Ca}^{2+}$

After incubation, erythrocytes were washed in Ringer solution and loaded with Fluo-3/ AM (Biotium, Hayward, USA) in Ringer solution containing $5 \mathrm{mM} \mathrm{CaCl}_{2}$ and $5 \mu \mathrm{M}$ Fluo-3/ $\mathrm{AM}$. The cells were incubated at $37^{\circ} \mathrm{C}$ for $30 \mathrm{~min}$. $\mathrm{Ca}^{2+}$-dependent fluorescence intensity was measured with an excitation wavelength of $488 \mathrm{~nm}$ and an emission wavelength of $530 \mathrm{~nm}$ on a FACS Calibur. The geomean of the $\mathrm{Ca}^{2+}$ dependent fluorescence was determined.

Reactive oxygen species (ROS)

Oxidative stress was determined utilizing 2',7'-dichlorodihydrofluorescein diacetate (DCFDA). After incubation, a $150 \mu \mathrm{l}$ suspension of erythrocytes was washed in Ringer solution and stained with DCFDA (Sigma, Schnelldorf, Germany) in Ringer solution containing DCFDA at a final concentration of $10 \mu \mathrm{M}$. Erythrocytes were incubated at $37^{\circ} \mathrm{C}$ for $30 \mathrm{~min}$ in the dark and washed two times in Ringer solution. The DCFDA-loaded erythrocytes were resuspended in $200 \mu \mathrm{l}$ Ringer solution and ROS-dependent fluorescence intensity was measured at an excitation wavelength of $488 \mathrm{~nm}$ and an emission wavelength of $530 \mathrm{~nm}$ on a FACS Calibur (BD). Subsequently, the geomean of the DCFDA dependent fluorescence was determined.

\section{Ceramide abundance}

For the determination of ceramide, a monoclonal antibody-based assay was used. To this end, cells were stained for 1 hour at $37^{\circ} \mathrm{C}$ with $1 \mu \mathrm{g} / \mathrm{ml}$ anti-ceramide antibody (clone MID 15B4, Alexis, Grünberg, Germany) in PBS containing 0.1\% bovine serum albumin (BSA) at a dilution of 1:10. The samples were washed twice with PBS-BSA. The cells were stained for 30 minutes with polyclonal fluorescein isothiocyanate (FITC) conjugated goat antimouse IgG and IgM specific antibody (Pharmingen, Hamburg, Germany) diluted 1:50 in PBSBSA. Unbound secondary antibody was removed by repeated washing with PBS-BSA. The samples were analysed by flow cytometric analysis with an excitation wavelength of 488 $\mathrm{nm}$ and an emission wavelength of $530 \mathrm{~nm}$. Finally, the geomean of the ceramide-dependent fluorescence was determined.

\section{Hemolysis}

For the determination of hemolysis, the samples were centrifuged ( $3 \mathrm{~min}$. at $1600 \mathrm{rpm}$ in room temperature) after incubation, and the supernatants were harvested. As a measure of hemolysis, the hemoglobin $(\mathrm{Hb})$ concentration of the supernatant was determined photometrically at $405 \mathrm{~nm}$. The absorption of the supernatant of erythrocytes lysed in distilled water was defined as $100 \%$ hemolysis.

\section{Statistics}

Data are expressed as arithmetic means \pm SEM. As indicated in the figure legends, statistical analysis was made using ANOVA with Tukey's test as post-test and $t$ test as appropriate. $\mathrm{n}$

Fig. 1. Effect of afatinib on phosphatidylserine exposure. A. Original histogram of annexin-Vbinding of erythrocytes following exposure for 48 hours to Ringer solution without (grey area) and with (black line) presence of $8 \mu \mathrm{g} /$ $\mathrm{ml}$ afatinib. B. Arithmetic means \pm SEM $(n=15)$ of

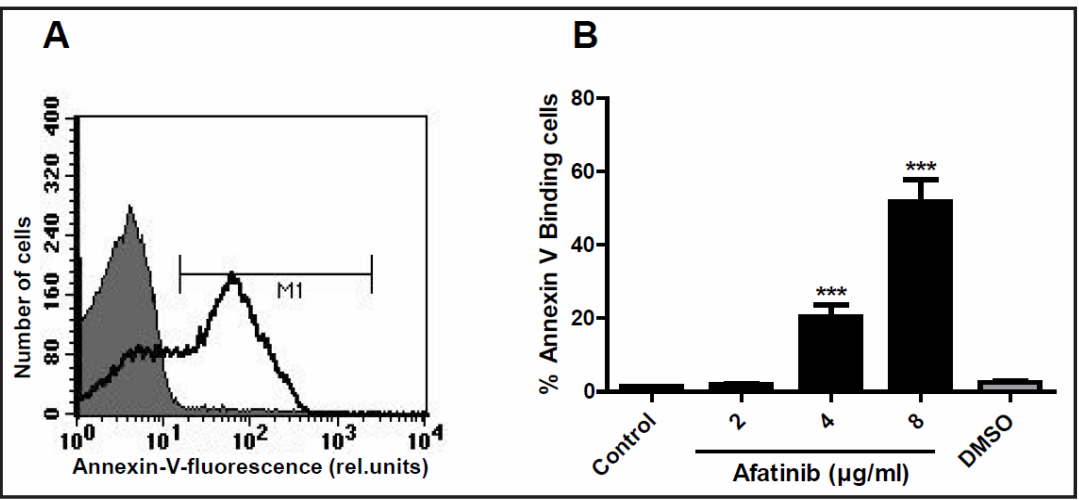
erythrocyte annexin-V-binding following incubation for 48 hours to Ringer solution without (Control) or with (black bars) afatinib (2-8 $\mathrm{\mu g} / \mathrm{ml}$ ). For comparison, the effect of the solvent DMSO is shown (grey bar). $* * *(p<0.001)$ indicates significant difference from the absence of afatinib (ANOVA). 
Fig. 2. Effect of Afatinib on erythrocyte forward scatter. A. Original histograms of forward scatter of erythrocytes following exposure for 48 hours to Ringer solution without (grey area) and with (black line) presence of $8 \mu \mathrm{g} / \mathrm{ml}$ Afatinib.B. Arithmetic means \pm SEM $(n=15)$ of the erythrocyte forward scatter (FSC) following incubation for

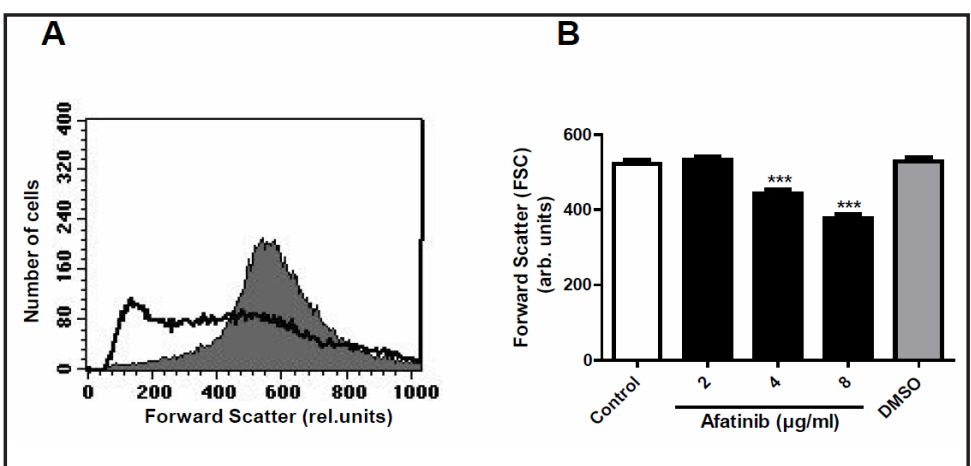
48 hours to Ringer solution without (white bar) or with (black bars) Afatinib (2 - $8 \mu \mathrm{g} / \mathrm{ml})$ or solvent DMSO alone (grey bar). ${ }^{* * *}(\mathrm{p}<0.001)$ indicates significant difference from the absence of afatinib (ANOVA).

Fig. 3. Effect of Afatinib on Fluo3 fluorescence. A. Original histograms of Fluo3 fluorescence reflecting cytosolic $\mathrm{Ca}^{2+}$ activity of erythrocytes following exposure for 48 hours to Ringer solution without (grey area) and with (black line) presence of $8 \mu \mathrm{g} / \mathrm{ml}$ Afatinib. B. Arithmetic means \pm SEM $(n=15)$ of the Fluo3 fluo-

A

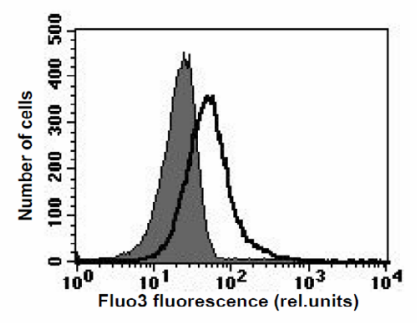

B

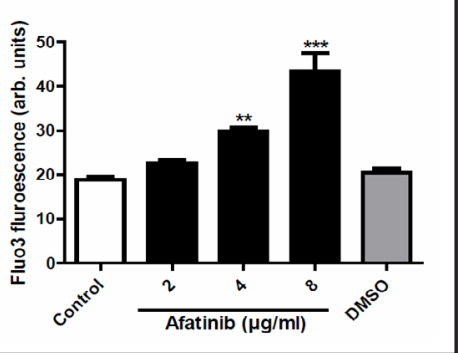

rescence in erythrocytes following incubation for 48 hours to Ringer solution without (white bar) or with (black bars) Afatinib $(2-8 \mu \mathrm{g} / \mathrm{ml})$ or solvent DMSO alone (grey bar). ${ }^{* *}(\mathrm{p}<0.01),{ }^{* * *}(\mathrm{p}<0.001)$ indicates significant difference from the absence of afatinib (ANOVA).

denotes the number of different erythrocyte specimens studied. Since different erythrocyte specimens used in distinct experiments are differently susceptible to triggers of eryptosis, the same erythrocyte specimens have been used for control and experimental conditions.

\section{Results}

The present study explored, whether afatinib stimulates eryptosis, the suicidal erythrocyte death. The most important hallmark of eryptosis is phospholipid scrambling of the cell membrane with phosphatidylserine translocation to the cell surface. Phosphatidylserine exposing erythrocytes were identified utilizing annexin-V-binding to phosphatidylserine, as determined by flow cytometry. Annexin-V-binding was analysed following an incubation of the erythrocytes for 48 hours in Ringer solution without or with afatinib $(2-8 \mu \mathrm{g} / \mathrm{ml})$. As illustrated in Fig. 1, a 48 hours exposure to afatinib increased the percentage of phosphatidylserine exposing erythrocytes, an effect reaching statistical significance at $4 \mu \mathrm{g} / \mathrm{ml}$ afatinib.

A second hallmark of eryptosis is erythrocyte shrinkage. As a measure of erythrocyte volume, forward scatter was determined utilizing flow cytometry. The measurements were performed after incubation for 48 hours in Ringer solution without or with afatinib (2 $8 \mu \mathrm{g} / \mathrm{ml}$ ). As shown in Fig, 2, afatinib decreased the erythrocyte forward scatter, an effect reaching statistical significance at $4 \mu \mathrm{g} / \mathrm{ml}$ afatinib.

Eryptosis could be triggered by increase of cytosolic $\mathrm{Ca}^{2+}$ activity $\left(\left[\mathrm{Ca}^{2+}\right]_{\mathrm{i}}\right)$. Fluo3 fluorescence was employed in order to quantify $\left[\mathrm{Ca}^{2+}\right]_{i}$. The erythrocytes were analyzed after a 48 hours incubation in Ringer solution without or with afatinib $(2-8 \mu \mathrm{g} / \mathrm{ml})$. As illustrated in Fig. 3, a 48 hours exposure to afatinib increased the Fluo3 fluorescence, an effect reaching 
Fig. 4. $\mathrm{Ca}^{2+}$ sensitivity of afatinib-induced phosphatidylserine exposure. A,B. Original histograms of annexinV-binding of erythrocytes following exposure for 48 hours to Ringer solution without (grey areas) and with (black lines) afatinib (8 $\mu \mathrm{g} / \mathrm{ml})$ in the presence (A) and absence (B) of extracellular $\mathrm{Ca}^{2+}$. C. Arithmetic means \pm SEM $(n=15)$ of annexinV-binding of erythrocytes after a 48 hours treatment with Ringer solution without (white bars) or with (black bars) afatinib $(8 \mu \mathrm{g} / \mathrm{ml})$ in the presence (left bars, $+\mathrm{Ca}^{2+}$ ) and absence (right bars, $-\mathrm{Ca}^{2+}$ ) of $\mathrm{Ca}^{2+}$. $*(\mathrm{p}<0.05), \quad * * *(\mathrm{p}<0.001) \quad$ indicates significant difference from the ab-

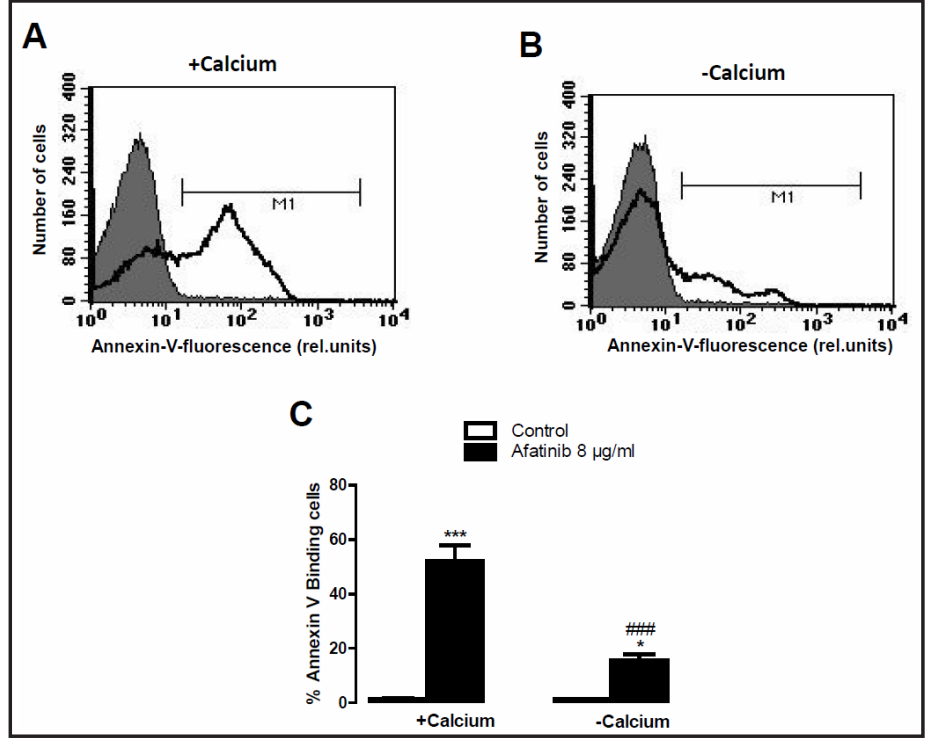
sence of afatinib, \#\#\#(p<0.001) indicates significant difference from the presence of $\mathrm{Ca}^{2+}(\mathrm{ANOVA})$.

Fig. 5. $\mathrm{Ca}^{2+}$ sensitivity of afatinibinduced decrease of forward scatter A,B. Original histograms of forward scatter of erythrocytes following exposure for 48 hours to Ringer solution without (grey areas) and with (black lines) afatinib $(8 \mu \mathrm{g} / \mathrm{ml})$ in the presence (A) and absence (B) of extracellular $\mathrm{Ca}^{2+}$. C. Arithmetic means \pm SEM $(n=15)$ of forward scatter of erythrocytes after a 48 hours treatment with Ringer solution without (white bars) or with (black bars) afatinib $(8 \mu \mathrm{g} / \mathrm{ml})$ in the presence (left bars, $+\mathrm{Ca}^{2+}$ ) and absence (right bars, $-\mathrm{Ca}^{2+}$ ) of $\mathrm{Ca}^{2+}$. $*(\mathrm{p}<0.05), \quad * * *(\mathrm{p}<0.001) \quad$ indicates significant difference from the ab-

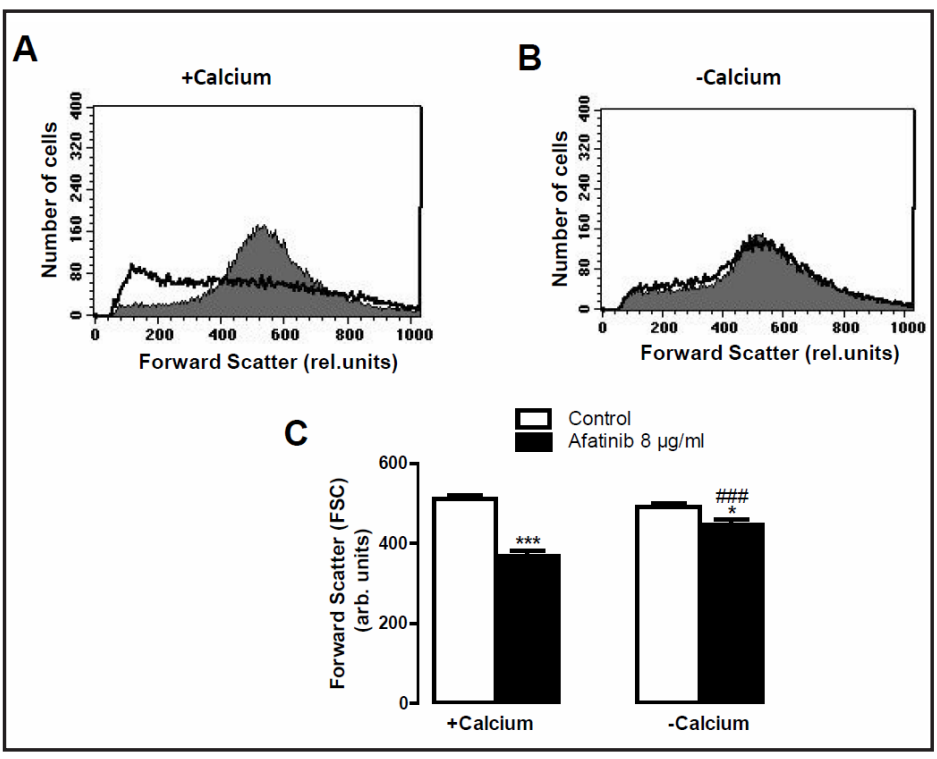
sence of afatinib, \#\#\# ( $<<0.001)$ indicates significant difference from the presence of $\mathrm{Ca}^{2+}(\mathrm{ANOVA})$.

Fig. 6. Effect of afatinib on reactive oxygen species. A. Original histogram of DCFDA fluorescence in erythrocytes following exposure for 48 hours to Ringer solution without (grey area) and with (black line) presence of $8 \mu \mathrm{g} / \mathrm{ml}$ afatinib. B. Arithmetic means \pm SEM $(n=13)$ of DCFDA fluorescence in erythrocytes following incubation for 48 hours to

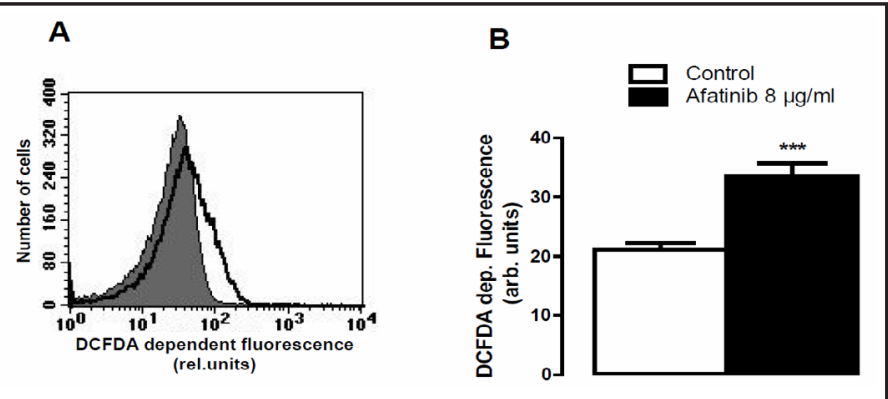
Ringer solution without (white bar) or with (black bar) afatinib $(8 \mu \mathrm{g} / \mathrm{ml}){ }^{* * *}(\mathrm{p}<0.001)$ indicates significant difference from the absence of afatinib (unpaired $t$ test).

statistical significance at $4 \mu \mathrm{g} / \mathrm{ml}$ afatinib. In this series of experiments, afatinib $(8 \mu \mathrm{g} / \mathrm{ml})$ significantly decreased the forward scatter from $533.00 \pm 16.61$ to $428.90 \pm 13.82(n=6)$. 
Fig. 7. $\mathrm{Ca}^{2+}$ sensitivity of afatinibinduced reactive oxygen species. A,B. Original histograms of DCFDA fluorescence of erythrocytes following exposure for 48 hours to Ringer solution without (grey areas) and with (black lines) afatinib $(8 \mu \mathrm{g} / \mathrm{ml})$ in the presence (A) and absence (B) of extracellular $\mathrm{Ca}^{2+}$. C. Arithmetic means \pm SEM $(\mathrm{n}=8)$ of DCFDA fluorescence of erythrocytes after a 48 hours treatment with Ringer solution without (white bars) or with (black bars) afatinib $(8 \mu \mathrm{g} / \mathrm{ml})$ in the presence (left bars, $+\mathrm{Ca}^{2+}$ ) and absence (right bars, $\left.-\mathrm{Ca}^{2+}\right)$ of $\mathrm{Ca}^{2+} .{ }^{* * *}(\mathrm{p}<0.001)$

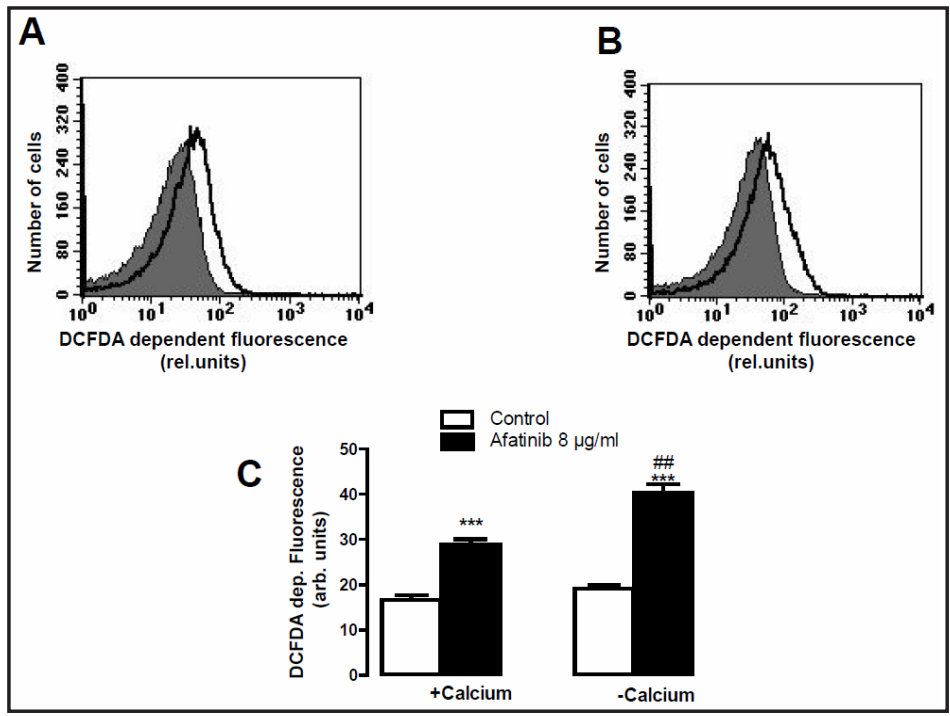
indicates significant difference from the absence of afatinib, $\# \#(\mathrm{p}<0.01)$ indicates significant difference from the presence of $\mathrm{Ca}^{2+}$ (ANOVA).

Fig. 8. Effect of afatinib on ceramide abundance. A. Original histogram of ceramide abundance at the surface of erythrocytes following exposure for 48 hours to Ringer solution without (grey area) and with (black line) presence of $8 \mu \mathrm{g}$ / $\mathrm{ml}$ afatinib. B. Arithmetic means \pm SEM ( $n=5)$ of ceramide abundance at the surface of erythrocytes following incubation for 48 hours to

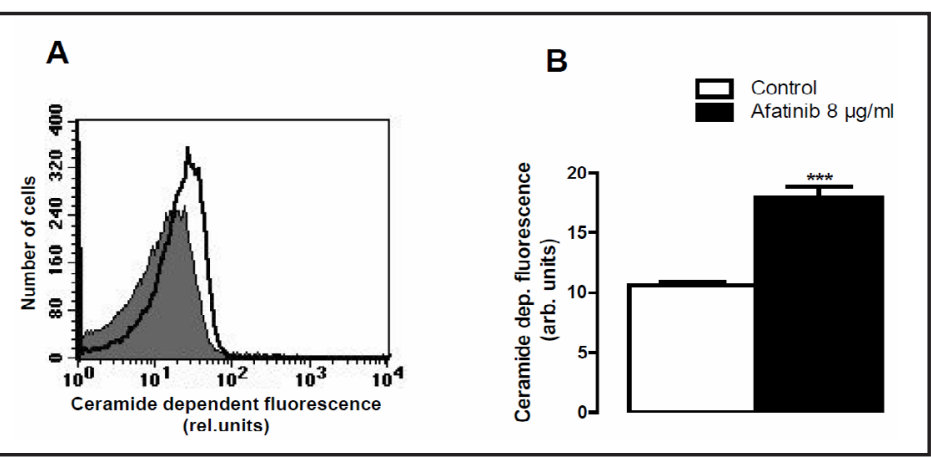
Ringer solution without (white bar) or with (black bar) afatinib $(8 \mu \mathrm{g} / \mathrm{ml}) .{ }^{* * *}(\mathrm{p}<0.01)$ indicates significant difference from the absence of afatinib (unpaired $t$ test).

In order to test whether afatinibinduced translocation of phosphatidylserine to the outside required entry of extracellular $\mathrm{Ca}^{2+}$, erythrocytes were incubated for 48 hours in the absence or presence of $8 \mu \mathrm{g} / \mathrm{ml}$ afatinib in the presence or nominal absence of extracellular $\mathrm{Ca}^{2+}$. As illustrated in Fig. 4, removal of extracellular $\mathrm{Ca}^{2+}$ significantly blunted the effect of afatinib on annexinV-binding. However, even in the absence of extracellular $\mathrm{Ca}^{2+}$, afatinib significantly increased the percentage of annexin- $\mathrm{V}$ binding erythrocytes. Thus, the afatinibinduced cell membrane scrambling was in part but not fully triggered by entry of extracellular $\mathrm{Ca}^{2+}$.

Similar observations were made on erythrocyte cell volume. As illustrated in Fig. 5, removal of extracellular $\mathrm{Ca}^{2+}$ significantly blunted the effect of afatinib

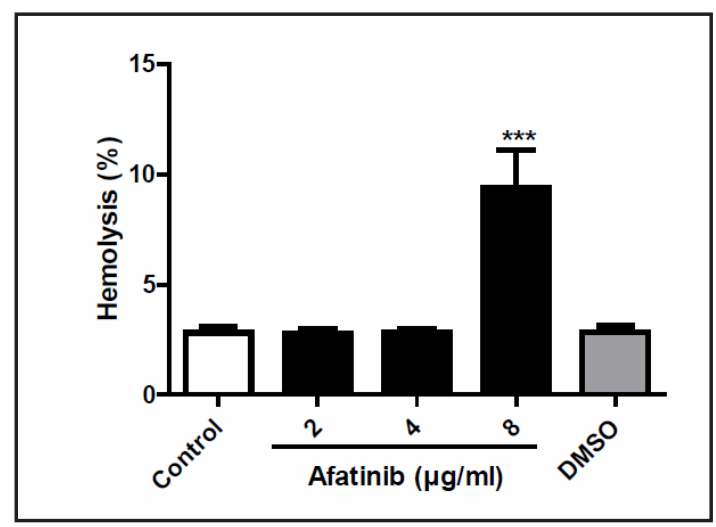

Fig. 9. Effect of afatinib on hemolysis. Arithmetic means \pm SEM $(n=5)$ of the percentage hemolytic erythrocytes following incubation for 48 hours to Ringer solution without (white bar) or with (black bar) afatinib $(2-8 \mu \mathrm{g} / \mathrm{ml}) .{ }^{* * *}(\mathrm{p}<0.001)$ indicates significant difference from the absence of afatinib (unpaired $t$ test). 
on forward scatter. However, even in the absence of extracellular $\mathrm{Ca}^{2+}$, afatinib significantly decreased the erythrocyte forward scatter. Thus, the afatinib-induced erythrocyte shrinkage was in part but not fully triggered by entry of extracellular $\mathrm{Ca}^{2+}$.

An additional series of experiments explored the theoretical possibility that afatinib was in part effective by modifying Akt activity. To this end experiments were performed in the absence and presence of Akt inhibitor A6730 (58 nM). As a result, the increase of the percentage of phosphatidylserine exposing erythrocytes following a 48 hours exposure to afatinib $(8 \mu \mathrm{g} / \mathrm{ml})$ was similar in the absence (from $2.46 \pm 0.52$ to $23.64 \pm 2.19 \%, \mathrm{n}=5$ ) and presence (from $4.07 \pm 0.47$ to $25.26 \pm 6.41 \%, \mathrm{n}=5$ ) of Akt inhibitor A6730 (58 nM).

Eryptosis is further stimulated by oxidative stress. Reactive oxygen species (ROS) was thus quantified utilizing $2^{\prime}, 7^{\prime}$-dichlorodihydrofluorescein diacetate (DCFDA). As illustrated in Fig. 6, a 48 hours exposure to afatinib $(8 \mu \mathrm{g} / \mathrm{ml})$ increased the DCFDA fluorescence of erythrocytes, observations pointing to afatinib induced oxidative stress. In this series of experiments, afatinib $(8 \mu \mathrm{g} / \mathrm{ml})$ significantly decreased the forward scatter from $484.30 \pm$ 10.21 to $436.00 \pm 18.60(n=8)$. The increase of DCFDA fluorescence was significantly more pronounced in the absence than in the presence of extracellular $\mathrm{Ca}^{2+}$ (Fig. 7).

A further stimulator of eryptosis is ceramide. Ceramide abundance at the erythrocyte surface was quantified utilizing specific antibodies. As illustrated in Fig. 8, a 48 hours exposure to afatinib $(8 \mu \mathrm{g} / \mathrm{ml})$ increased the ceramide abundance at the erythrocyte surface. In this series of experiments, afatinib $(8 \mu \mathrm{g} / \mathrm{ml})$ significantly decreased the forward scatter from $483.50 \pm 8.78$ to $424.60 \pm 15.38(\mathrm{n}=10)$. The increase of ceramide abundance following a 48 hours exposure to afatinib ( $8 \mu \mathrm{g} / \mathrm{ml}$ ) was similar in the presence (from $9.59 \pm 0.24$ to 12.84 \pm 0.86 a.u., $\mathrm{n}=5$ ) and absence (from $11.64 \pm 0.81$ to $14.08 \pm 0.43$ a.u., $\mathrm{n}=5$ ) of extracellular $\mathrm{Ca}^{2+}$. The increase of ceramide abundance following a 48 hours exposure to afatinib $(8 \mu \mathrm{g} /$ $\mathrm{ml}$ ) was further similar in the absence (from $9.41 \pm 0.29$ to $11.63 \pm 0.29$ a.u., $\mathrm{n}=5$ ) and presence (from $9.33 \pm 0.26$ to $11.79 \pm 0.39$ a.u., $\mathrm{n}=5$ ) of Akt inhibitor $\mathrm{A6730}(58 \mathrm{nM})$.

A final series of experiments addressed the effect of afatinib on hemolysis, as evident from the haemoglobin concentration in the supernatant. As illustrated in Fig. 9, a 48 hours exposure to afatinib at $8 \mu \mathrm{g} / \mathrm{ml}$, but not at lower concentrations increased the percentage of hemolytic erythrocytes.

\section{Discussion}

The present observations reveal that afatinib stimulates cell membrane scrambling with phosphatidylserine translocation to the erythrocyte surface, and triggers erythrocyte shrinkage, apparent from a decrease of forward scatter. Cell membrane scrambling and cell shrinkage are hallmarks of eryptosis, the suicidal erythrocyte death. The afatinib concentrations required for the stimulation of eryptosis are within the range of concentrations encountered in the plasma of patients [43]. The stimulation of eryptosis may thus well explain the anemia following afatinib treatment [31].

The effect of afatinib on cell membrane scrambling was paralleled by an increase of cytosolic $\mathrm{Ca}^{2+}$ activity $\left(\left[\mathrm{Ca}^{2+}\right]_{\mathrm{i}}\right)$ and was in large part dependent on $\mathrm{Ca}^{2+}$ entry from the extracellular space. Removal of extracellular $\mathrm{Ca}^{2+}$ significantly blunted the afatinib induced eryptosis. However, afatinib triggered cell membrane scrambling even in the nominal absence of extracellular $\mathrm{Ca}^{2+}$, an observation pointing to the involvement of additional mechanisms contributing to afatinib induced cell membrane scrambling. Cells could be sensitized for the scrambling effect of $\mathrm{Ca}^{2+}$ by ceramide [58]. Afatinib treatment indeed increased the ceramide abundance at the erythrocyte surface. Moreover, afatinib significantly enhanced the abundance of reactive oxygen species, a further known stimulator of eryptosis [58]. Accordingly, afatinib is in part effective by inducing oxidative stress.

The effect of afatinib on cell membrane scrambling was paralleled by erythrocyte shrinkage. The effect is significantly blunted by $\mathrm{Ca}^{2+}$ removal and is presumably in large part due to increase of $\left[\mathrm{Ca}^{2+}\right]_{\mathrm{i}}$ with subsequent activation of $\mathrm{Ca}^{2+}$ sensitive $\mathrm{K}^{+}$channels, $\mathrm{K}^{+}$exit, cell membrane hyperpolarization, $\mathrm{Cl}^{-}$exit and thus cellular loss of $\mathrm{KCl}$ with water.

\section{KARGER}




\section{Cellular Physiology Cell Physiol Biochem 2018;47:1259-1273 \begin{tabular}{l|l} 
DOI: 10.1159/000490221 & and Biochemistry \\
Published online: June 19, 2018 & $\begin{array}{l}\text { (2018 The Author(s). Published by S. Karger AG, Basel } \\
\text { www.karger.com/cpb }\end{array}$ \\
\cline { 2 - 3 }
\end{tabular} \\ Al Mamun Bhuyan/Lang: Afatinib-Induced Eryptosis}

Phosphatidylserine exposing erythrocytes are rapidly cleared from circulating blood and stimulation of eryptosis may lead to anemia as soon as the loss of erythrocytes surpasses the formation of new erythrocytes by erythropoiesis [58]. Stimulation of eryptosis may further compromize microcirculation [62, 142-146] as phosphatidylserine exposing erythrocytes adhere to the vascular wall [147], stimulate blood clotting and trigger thrombosis [142, 148, 149]. On the other hand, eryptosis may precede and thus prevent hemolysis [58] with release of hemoglobin, which could pass the renal glomerular filter, precipitate in the acidic lumen of renal tubules, occlude nephrons and may thus lead to renal failure [150].

In conclusion, afatinib triggers erythrocyte cell membrane scrambling, an effect in part due to $\mathrm{Ca}^{2+}$ entry, oxidative stress as well as ceramide.

\section{Acknowledgements}

The authors acknowledge the meticulous preparation of the manuscript by Lejla Subasic. The study was supported by the Deutsche Forschungsgemeinschaft and the open access publishing fund of the University Tübingen.

\section{Disclosure Statement}

The authors declare to have no conflict of interests.

\section{References}

1 Dong L, Lei D, Zhang H: Clinical strategies for acquired epidermal growth factor receptor tyrosine kinase inhibitor resistance in non-small-cell lung cancer patients. Oncotarget 2017;8:64600-64606.

-2 Mazza V, Cappuzzo F: Treating EGFR mutation resistance in non-small cell lung cancer - role of osimertinib. Appl Clin Genet 2017;10:49-56.

3 Russo A, Franchina T, Ricciardi GRR, Smiroldo V, Picciotto M, Zanghi M, Rolfo C, Adamo V: Third generation EGFR TKIs in EGFR-mutated NSCLC: Where are we now and where are we going. Crit Rev Oncol Hematol 2017;117:38-47.

4 Santarpia M, Liguori A, Karachaliou N, Gonzalez-Cao M, Daffina MG, D'Aveni A, Marabello G, Altavilla G, Rosell R: Osimertinib in the treatment of non-small-cell lung cancer: design, development and place in therapy. Lung Cancer (Auckl) 2017;8:109-125.

-5 Zhang Y, Miao S, Wang F, Fang W, Chen G, Chen X, Yan F, Huang X, Wu M, Huang Y, Zhang L: The efficacy and toxicity of afatinib in advanced EGFR-positive non-small-cell lung cancer patients after failure of firstgeneration tyrosine kinase inhibitors: a systematic review and meta-analysis. J Thorac Dis 2017;9:19801987.

6 Aw DC, Tan EH, Chin TM, Lim HL, Lee HY, Soo RA: Management of epidermal growth factor receptor tyrosine kinase inhibitor-related cutaneous and gastrointestinal toxicities. Asia Pac J Clin Oncol 2017;10.1111/ajco.12687

-7 Paz-Ares L, Tan EH, O'Byrne K, Zhang L, Hirsh V, Boyer M, Yang JC, Mok T, Lee KH, Lu S, Shi Y, Lee DH, Laskin J, Kim DW, Laurie SA, Kolbeck K, Fan J, Dodd N, Marten A, Park K: Afatinib versus gefitinib in patients with EGFR mutation-positive advanced non-small-cell lung cancer: overall survival data from the phase IIb LUXLung 7 trial. Ann Oncol 2017;28:270-277.

8 Corallo S, D'Argento E, Strippoli A, Basso M, Monterisi S, Rossi S, Cassano A, Barone CM: Treatment Options for EGFR T790M-Negative EGFR Tyrosine Kinase Inhibitor-Resistant Non-Small Cell Lung Cancer. Target Oncol 2017;12:153-161.

-9 Lee DH: Treatments for EGFR-mutant non-small cell lung cancer (NSCLC): The road to a success, paved with failures. Pharmacol Ther 2017;174:1-21.

10 Liao BC, Lin CC, Yang JC: Novel EGFR Inhibitors in Non-small Cell Lung Cancer: Current Status of Afatinib. Curr Oncol Rep 2017;19:4. 


\section{Cellular Physiology Cell Physiol Biochem 2018;47:1259-1273 \begin{tabular}{lll} 
DOI: 10.1159/000490221 & and Biochemistry & $\begin{array}{l}\text { O 2018 The Author(s). Published by S. Karger AG, Basel } \\
\text { www.karger.com/cpb }\end{array}$ \\
\cline { 2 - 3 }
\end{tabular}}

Al Mamun Bhuyan/Lang: Afatinib-Induced Eryptosis

11 Minari R, Bordi P, Tiseo M: Third-generation epidermal growth factor receptor-tyrosine kinase inhibitors in T790M-positive non-small cell lung cancer: review on emerged mechanisms of resistance. Transl Lung Cancer Res 2016;5:695-708.

12 Proto C, Imbimbo M, Gallucci R, Brissa A, Signorelli D, Vitali M, Macerelli M, Corrao G, Ganzinelli M, Greco FG, Garassino MC, Lo Russo G: Epidermal growth factor receptor tyrosine kinase inhibitors for the treatment of central nervous system metastases from non-small cell lung cancer: the present and the future. Transl Lung Cancer Res 2016;5:563-578.

13 Sullivan I, Planchard D: Next-Generation EGFR Tyrosine Kinase Inhibitors for Treating EGFR-Mutant Lung Cancer beyond First Line. Front Med (Lausanne) 2016;3:76.

14 Passaro A, Guerini-Rocco E, Pochesci A, Vacirca D, Spitaleri G, Catania CM, Rappa A, Barberis M, de Marinis F: Targeting EGFR T790M mutation in NSCLC: From biology to evaluation and treatment. Pharmacol Res 2017;117:406-415.

15 Liao BC, Lin CC, Lee JH, Yang JC: Update on recent preclinical and clinical studies of T790M mutant-specific irreversible epidermal growth factor receptor tyrosine kinase inhibitors. J Biomed Sci 2016;23:86.

16 Pakkala S, Ramalingam SS: Epidermal Growth Factor Receptor Mutated Advanced Non-Small Cell Lung Cancer: A Changing Treatment Paradigm. Hematol Oncol Clin North Am 2017;31:83-99.

17 Zhang H: Three generations of epidermal growth factor receptor tyrosine kinase inhibitors developed to revolutionize the therapy of lung cancer. Drug Des Devel Ther 2016;10:3867-3872.

18 Ding PN, Roberts TL, Chua W, Becker TM, Descallar J, Yip PY, Bray VJ: Clinical outcomes in patients with advanced EGFR-mutated non-small cell lung cancer in South Western Sydney Local Health District. Intern Med J 2017;10.1111/imj.13555

19 Liao BC, Lin CC, Lee JH, Yang JC: Optimal management of EGFR-mutant non-small cell lung cancer with disease progression on first-line tyrosine kinase inhibitor therapy. Lung Cancer 2017;110:7-13.

-20 Proto C, Lo Russo G, Corrao G, Ganzinelli M, Facchinetti F, Minari R, Tiseo M, Garassino MC: Treatment in EGFR-mutated non-small cell lung cancer: how to block the receptor and overcome resistance mechanisms. Tumori 2017;103:325-337.

-21 Batson S, Mitchell SA, Windisch R, Damonte E, Munk VC, Reguart N: Tyrosine kinase inhibitor combination therapy in first-line treatment of non-small-cell lung cancer: systematic review and network meta-analysis. Onco Targets Ther 2017;10:2473-2482.

22 Eze C, Hegemann NS, Roengvoraphoj O, Dantes M, Manapov F: Concurrent Afatinib and Whole-Brain Radiotherapy in Exon 19-del-EGFR Mutant Lung Adenocarcinoma: A Case Report and Mini Review of the Literature. Front Oncol 2017;7:88.

23 Hirsh V: New developments in the treatment of advanced squamous cell lung cancer: focus on afatinib. Onco Targets Ther 2017;10:2513-2526.

24 Kutkowska J, Porebska I, Rapak A: Non-small cell lung cancer - mutations, targeted and combination therapy. Postepy Hig Med Dosw (Online) 2017;71:431-445.

-25 Morin-Ben Abdallah S, Hirsh V: Epidermal Growth Factor Receptor Tyrosine Kinase Inhibitors in Treatment of Metastatic Non-Small Cell Lung Cancer, with a Focus on Afatinib. Front Oncol 2017;7:97.

-26 Ricciuti B, Baglivo S, Paglialunga L, De Giglio A, Bellezza G, Chiari R, Crino L, Metro G: Osimertinib in patients with advanced epidermal growth factor receptor T790M mutation-positive non-small cell lung cancer: rationale, evidence and place in therapy. Ther Adv Med Oncol 2017;9:387-404.

-27 Aggarwal C, Borghaei H: Treatment Paradigms for Advanced Non-Small Cell Lung Cancer at Academic Medical Centers: Involvement in Clinical Trial Endpoint Design. Oncologist 2017;22:700-708.

28 Juan 0, Popat S: Treatment choice in epidermal growth factor receptor mutation-positive non-small cell lung carcinoma: latest evidence and clinical implications. Ther Adv Med Oncol 2017;9:201-216.

29 Roviello G, Zanotti L, Cappelletti MR, Gobbi A, Dester M, Paganini G, Pacifico C, Generali D, Roudi R: Are EGFR tyrosine kinase inhibitors effective in elderly patients with EGFR-mutated non-small cell lung cancer? Clin Exp Med 2017;10.1007/s10238-017-0460-7

-30 Liu TC, Jin X, Wang Y, Wang K: Role of epidermal growth factor receptor in lung cancer and targeted therapies. Am J Cancer Res 2017;7:187-202.

-31 Passiglia F, Listi A, Castiglia M, Perez A, Rizzo S, Bazan V, Russo A: EGFR inhibition in NSCLC: New findings.... and opened questions? Crit Rev Oncol Hematol 2017;112:126-135.

-32 Yang Z, Hackshaw A, Feng Q, Fu X, Zhang Y, Mao C, Tang J: Comparison of gefitinib, erlotinib and afatinib in non-small cell lung cancer: A meta-analysis. Int J Cancer 2017;140:2805-2819. 


\section{Cellular Physiology Cell Physiol Biochem 2018;47:1259-1273 \begin{tabular}{l|l} 
DOI: 10.1159/000490221 & Ond Biochemistry \\
Published online: June 19, 2018 & $\begin{array}{l}\text { 2018 The Author(s). Published by S. Karger AG, Basel } \\
\text { www.karger.com/cpb }\end{array}$ \\
\cline { 2 - 3 }
\end{tabular}}

Al Mamun Bhuyan/Lang: Afatinib-Induced Eryptosis

-33 Bruckl W, Tufman A, Huber RM: Advanced non-small cell lung cancer (NSCLC) with activating EGFR mutations: first-line treatment with afatinib and other EGFR TKIs. Expert Rev Anticancer Ther 2017;17:143-155.

-34 Keating GM: Afatinib: A Review in Advanced Non-Small Cell Lung Cancer. Target Oncol 2016;11:825-835.

- 35 Kohler J: Second-Line Treatment of NSCLC-The Pan-ErbB Inhibitor Afatinib in Times of Shifting Paradigms. Front Med (Lausanne) 2017;4:9.

-36 Rossi A, Maione P, Santabarbara G, Sacco PC, Casaluce F, Sgambato A, Barzelloni ML, Palazzolo G, Gridelli C: The safety of second-line treatment options for non-small cell lung cancer. Expert Opin Drug Saf 2017;16:471-479.

-37 Shum E, Wang F, Kim S, Perez-Soler R, Cheng H: Investigational therapies for squamous cell lung cancer: from animal studies to phase II trials. Expert Opin Investig Drugs 2017;26:415-426.

38 Zhang YC, Zhou Q, Wu YL: Emerging challenges of advanced squamous cell lung cancer. ESMO Open 2016;1:e000129.

39 Silva AP, Coelho PV, Anazetti M, Simioni PU: Targeted therapies for the treatment of non-small-cell lung cancer: Monoclonal antibodies and biological inhibitors. Hum Vaccin Immunother 2017;13:843-853.

40 Sun JM, Park K: Can we define the optimal sequence of epidermal growth factor receptor tyrosine kinase inhibitors for the treatment of epidermal growth factor receptor-mutant nonsmall cell lung cancer? Curr Opin Oncol 2017;29:89-96.

41 Mukai H, Masuda N, Ishiguro H, Mitsuma A, Shibata T, Yamamura J, Toi M, Watabe A, Sarashina A, Uttenreuther-Fischer M, Ando Y: Phase I trial of afatinib plus vinorelbine in Japanese patients with advanced solid tumors, including breast cancer. Cancer Chemother Pharmacol 2015;76:739-750.

-42 Patras de Campaigno E, Bondon-Guitton E, Laurent G, Montastruc F, Montastruc JL, Lapeyre-Mestre M, Despas F: Identification of cellular targets involved in cardiac failure caused by PKI in oncology: an approach combining pharmacovigilance and pharmacodynamics. Br J Clin Pharmacol 2017;83:1544-1555.

-43 Chu QS, Sangha R, Hotte SJ, Sergenson G, Schnell D, Chand VK, Hirte HW: A phase I, dose-escalation trial of continuous- and pulsed-dose afatinib combined with pemetrexed in patients with advanced solid tumors. Invest New Drugs 2014;32:1226-1235.

44 Chao TT, Wang CY, Chen YL, Lai CC, Chang FY, Tsai YT, Chao CH, Shiau CW, Huang YC, Yu CJ, Chen KF: Afatinib induces apoptosis in NSCLC without EGFR mutation through Elk-1-mediated suppression of CIP2A. Oncotarget 2015;6:2164-2179.

45 Guan SS, Chang J, Cheng CC, Luo TY, Ho AS, Wang CC, Wu CT, Liu SH: Afatinib and its encapsulated polymeric micelles inhibits HER2-overexpressed colorectal tumor cell growth in vitro and in vivo. Oncotarget 2014;5:4868-4880.

46 Hu X, Shi S, Wang H, Yu X, Wang Q, Jiang S, Ju D, Ye L, Feng M: Blocking autophagy improves the anti-tumor activity of afatinib in lung adenocarcinoma with activating EGFR mutations in vitro and in vivo. Sci Rep 2017;7:4559.

47 Liu X, Lv Z, Zou J, Liu X, Ma J, Wang J, Sa N, Jing P, Xu W: Afatinib down-regulates MCL-1 expression through the PERK-eIF2alpha-ATF4 axis and leads to apoptosis in head and neck squamous cell carcinoma. Am J Cancer Res 2016;6:1708-1719.

48 Liu YH, Zhu WL: Effects of cetuximab combined with afatinib on the expression of KDR and AQP1 in lung cancer. Genet Mol Res 2015;14:16652-16661.

-49 Mao X, Chen Z, Zhao Y, Yu Y, Guan S, Woodfield SE, Vasudevan SA, Tao L, Pang JC, Lu J, Zhang H, Zhang F, Yang J: Novel multi-targeted ErbB family inhibitor afatinib blocks EGF-induced signaling and induces apoptosis in neuroblastoma. Oncotarget 2017;8:1555-1568.

50 Modjtahedi H, Cho BC, Michel MC, Solca F: A comprehensive review of the preclinical efficacy profile of the ErbB family blocker afatinib in cancer. Naunyn Schmiedebergs Arch Pharmacol 2014;387:505-521.

51 Pancewicz-Wojtkiewicz J, Bernatowicz PL: The Effect of Afatinib Treatment in Non-small Cell Lung Cancer Cells. Anticancer Res 2017;37:3543-3546.

52 Tang Y, Zhang X, Qi F, Chen M, Li Y, Liu L, He W, Li Z, Zu X: Afatinib inhibits proliferation and invasion and promotes apoptosis of the T24 bladder cancer cell line. Exp Ther Med 2015;9:1851-1856.

-53 Tsai YC, Yeh CH, Tzen KY, Ho PY, Tuan TF, Pu YS, Cheng AL, Cheng JC: Targeting epidermal growth factor receptor/human epidermal growth factor receptor 2 signalling pathway by a dual receptor tyrosine kinase inhibitor afatinib for radiosensitisation in murine bladder carcinoma. Eur J Cancer 2013;49:1458-1466. 


\section{Cellular Physiology Cell Physiol Biochem 2018;47:1259-1273 \begin{tabular}{l|l} 
DOI: 10.1159/000490221 & and Biochemistry \\
Published online: June 19, 2018 & $\begin{array}{l}\text { 2018 The Author(s). Published by S. Karger AG, Basel } \\
\text { www.karger.com/cpb }\end{array}$ \\
\cline { 2 - 3 }
\end{tabular}}

Al Mamun Bhuyan/Lang: Afatinib-Induced Eryptosis

54 Wong CH, Ma BB, Hui CW, Tao Q, Chan AT: Preclinical evaluation of afatinib (BIBW2992) in esophageal squamous cell carcinoma (ESCC). Am J Cancer Res 2015;5:3588-3599.

55 Yonesaka K, Kudo K, Nishida S, Takahama T, Iwasa T, Yoshida T, Tanaka K, Takeda M, Kaneda H, Okamoto I, Nishio K, Nakagawa K: The pan-HER family tyrosine kinase inhibitor afatinib overcomes HER3 ligand heregulin-mediated resistance to EGFR inhibitors in non-small cell lung cancer. Oncotarget 2015;6:3360233611.

56 Zhan WJ, Zhu JF, Wang LM: Inhibition of proliferation and induction of apoptosis in RB116 retinoblastoma cells by afatinib treatment. Tumour Biol 2016;37:9249-9254.

57 Zhang S, Zheng X, Huang H, Wu K, Wang B, Chen X, Ma S: Afatinib increases sensitivity to radiation in nonsmall cell lung cancer cells with acquired EGFR T790M mutation. Oncotarget 2015;6:5832-5845.

58 Lang E, Lang F: Mechanisms and pathophysiological significance of eryptosis, the suicidal erythrocyte death. Semin Cell Dev Biol 2015;39:35-42.

59 Gusev GP, Govekar R, Gadewal N, Agalakova NI: Understanding quasi-apoptosis of the most numerous enucleated components of blood needs detailed molecular autopsy. Ageing Res Rev 2017;35:46-62.

60 Qadri SM, Bissinger R, Solh Z, Oldenborg PA: Eryptosis in health and disease: A paradigm shift towards understanding the (patho)physiological implications of programmed cell death of erythrocytes. Blood Rev 2017;31:349-361.

61 Lang PA, Kaiser S, Myssina S, Wieder T, Lang F, Huber SM: Role of Ca2+-activated K+ channels in human erythrocyte apoptosis. Am J Physiol Cell Physiol 2003;285:C1553-C1560.

62 Abed M, Towhid ST, Mia S, Pakladok T, Alesutan I, Borst O, Gawaz M, Gulbins E, Lang F: Sphingomyelinaseinduced adhesion of eryptotic erythrocytes to endothelial cells. Am J Physiol Cell Physiol 2012;303:C991999.

63 Lau IP, Chen H, Wang J, Ong HC, Leung KC, Ho HP, Kong SK: In vitro effect of CTAB- and PEG-coated gold nanorods on the induction of eryptosis/erythroptosis in human erythrocytes. Nanotoxicology 2012;6:847856.

64 Maellaro E, Leoncini S, Moretti D, Del Bello B, Tanganelli I, De Felice C, Ciccoli L: Erythrocyte caspase-3 activation and oxidative imbalance in erythrocytes and in plasma of type 2 diabetic patients. Acta Diabetol 2013;50:489-495.

65 Bissinger R, Lang E, Ghashghaeinia M, Singh Y, Zelenak C, Fehrenbacher B, Honisch S, Chen H, Fakhri H, Umbach AT, Liu G, Rexhepaj R, Liu G, Schaller M, Mack AF, Lupescu A, Birnbaumer L, Lang F, Qadri SM: Blunted apoptosis of erythrocytes in mice deficient in the heterotrimeric G-protein subunit Galphai2. Sci Rep 2016;6:30925.

66 Lang E, Bissinger R, Fajol A, Salker MS, Singh Y, Zelenak C, Ghashghaeinia M, Gu S, Jilani K, Lupescu A, Reyskens KM, Ackermann TF, Foller M, Schleicher E, Sheffield WP, Arthur JS, Lang F, Qadri SM: Accelerated apoptotic death and in vivo turnover of erythrocytes in mice lacking functional mitogen- and stressactivated kinase MSK1/2. Sci Rep 2015;5:17316.

67 Qadri SM, Chen D, Schubert P, Perruzza DL, Bhakta V, Devine DV, Sheffield WP: Pathogen inactivation by riboflavin and ultraviolet light illumination accelerates the red blood cell storage lesion and promotes eryptosis. Transfusion 2017;57:661-673.

-68 Qadri SM, Chen D, Schubert P, Devine DV, Sheffield WP: Early gamma-irradiation and subsequent storage of red cells in SAG-M additive solution potentiate energy imbalance, microvesiculation and susceptibility to stress-induced apoptotic cell death. Vox Sang 2017;112:480-483.

69 Macczak A, Cyrkler M, Bukowska B, Michalowicz J: Eryptosis-inducing activity of bisphenol A and its analogs in human red blood cells (in vitro study). J Hazard Mater 2016;307:328-335.

70 Officioso A, Manna C, Alzoubi K, Lang F: Bromfenvinphos induced suicidal death of human erythrocytes. Pestic Biochem Physiol 2016;126:58-63.

71 Qadri SM, Donkor DA, Bhakta V, Eltringham-Smith LJ, Dwivedi DJ, Moore JC, Pepler L, Ivetic N, Nazi I, Fox-Robichaud AE, Liaw PC, Sheffield WP: Phosphatidylserine externalization and procoagulant activation of erythrocytes induced by Pseudomonas aeruginosa virulence factor pyocyanin. J Cell Mol Med 2016;10.1111/jcmm.12778

72 Zierle J, Bissinger R, Bouguerra G, Abbes S, Lang F: Triggering of Suicidal Erythrocyte Death by Regorafenib. Cell Physiol Biochem 2016;38:160-172.

73 Pagano M, Faggio C: The use of erythrocyte fragility to assess xenobiotic cytotoxicity. Cell Biochem Funct 2015;33:351-355. 


\section{Cellular Physiology Cell Physiol Biochem 2018;47:1259-1273

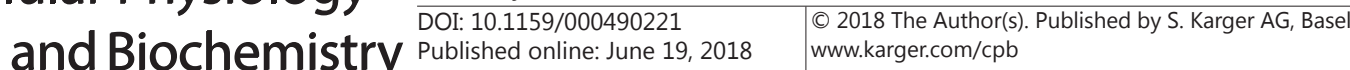

74 Al Mamun Bhuyan A, Signoretto E, Bissinger R, Lang F: Enhanced Eryptosis Following Exposure to Dolutegravir. Cell Physiol Biochem 2016;39:639-650.

75 Al Mamun Bhuyan A, Signoretto E, Lang F: Triggering of Suicidal Erythrocyte Death by Psammaplin A. Cell Physiol Biochem 2016;39:908-918.

76 Almasry M, Jemaa M, Mischitelli M, Faggio C, Lang F: Stimulation of Suicidal Erythrocyte Death by Phosphatase Inhibitor Calyculin A. Cell Physiol Biochem 2016;40:163-171.

-77 Bissinger R, Bhuyan AA, Signoretto E, Lang F: Stimulating Effect of Elvitegravir on Suicidal Erythrocyte Death. Cell Physiol Biochem 2016;38:1111-1120.

-78 Egler J, Zierle J, Lang F: Stimulating Effect of Manumycin A on Suicidal Erythrocyte Death. Cell Physiol Biochem 2016;38:1147-1156.

-79 Mischitelli M, Jemaa M, Almasry M, Faggio C, Lang F: Stimulation of Erythrocyte Cell Membrane Scrambling by Quinine. Cell Physiol Biochem 2016;40:657-667.

80 Mischitelli M, Jemaa M, Almasry M, Faggio C, Lang F: Stimulation of Suicidal Erythrocyte Death by Rottlerin. Cell Physiol Biochem 2016;40:558-566.

81 Mischitelli M, Jemaa M, Almasry M, Faggio C, Lang F: Triggering of Suicidal Erythrocyte Death by Fascaplysin. Cell Physiol Biochem 2016;39:1638-1647.

82 Mischitelli M, Jemaa M, Almasry M, Faggio C, Lang F: Ca2+ Entry, Oxidative Stress, Ceramide and Suicidal Erythrocyte Death Following Diosgenin Treatment. Cell Physiol Biochem 2016;39:1626-1637.

-83 Mischitelli M, Jemaa M, Almasry M, Faggio C, Lang F: Triggering of Erythrocyte Cell Membrane Scrambling by Emodin. Cell Physiol Biochem 2016;40:91-103.

84 Peter T, Bissinger R, Lang F: Stimulation of Eryptosis by Caspofungin. Cell Physiol Biochem 2016;39:939949.

85 Peter T, Bissinger R, Liu G, Lang F: Anidulafungin-Induced Suicidal Erythrocyte Death. Cell Physiol Biochem 2016;38:2272-2284.

86 Peter T, Bissinger R, Signoretto E, Mack AF, Lang F: Micafungin-Induced Suicidal Erythrocyte Death. Cell Physiol Biochem 2016;39:584-595.

87 Pretorius E, du Plooy JN, Bester J: A Comprehensive Review on Eryptosis. Cell Physiol Biochem 2016;39:1977-2000.

-88 Shan F, Yang R, Ji T, Jiao F: Vitamin C Inhibits Aggravated Eryptosis by Hydrogen Peroxide in Glucose-6Phosphated Dehydrogenase Deficiency. Cell Physiol Biochem 2016;39:1453-1462.

89 Signoretto E, Honisch S, Briglia M, Faggio C, Castagna M, Lang F: Nocodazole Induced Suicidal Death of Human Erythrocytes. Cell Physiol Biochem 2016;38:379-392.

90 Signoretto E, Laufer SA, Lang F: Stimulating Effect of Sclareol on Suicidal Death of Human Erythrocytes. Cell Physiol Biochem 2016;39:554-564.

91 Signoretto E, Zierle J, Bissinger R, Castagna M, Bossi E, Lang F: Triggering of Suicidal Erythrocyte Death by Pazopanib. Cell Physiol Biochem 2016;38:926-938.

\$2 Wesseling MC, Wagner-Britz L, Huppert H, Hanf B, Hertz L, Nguyen DB, Bernhardt I: Phosphatidylserine Exposure in Human Red Blood Cells Depending on Cell Age. Cell Physiol Biochem 2016;38:1376-1390.

\$3 Zierle J, Bissinger R, Lang F: Inhibition by Teriflunomide of Erythrocyte Cell Membrane Scrambling Following Energy Depletion, Oxidative Stress and Ionomycin. Cell Physiol Biochem 2016;39:1877-1890.

94 Al Mamun Bhuyan A, Bissinger R, Cao H, Lang F: Triggering of Suicidal Erythrocyte Death by bexaroten. Cell Physiol Biochem 2016;in press.:

-95 Farag MR, Alagawany M: Erythrocytes as a biological model for screening of xenobiotics toxicity. Chem Biol Interact 2018;279:73-83.

-96 Ray RR: Adverse hematological effects of hexavalent chromium: an overview. Interdiscip Toxicol 2016;9:55-65.

-97 Al Mamun Bhuyan A, Bissinger R, Cao H, Lang F: Triggering of Suicidal Erythrocyte Death by Exemestane. Cell Physiol Biochem 2017;42:1-12.

-98 Swanepoel AC, Emmerson 0, Pretorius E: Effect of Progesterone and Synthetic Progestins on Whole Blood Clot Formation and Erythrocyte Structure. Microsc Microanal 2017;23:607-617.

$\$ 99$ Swanepoel AC, Emmerson O, Pretorius E: The Effect of Endogenous and Synthetic Estrogens on Whole Blood Clot Formation and Erythrocyte Structure. Microsc Microanal 2017;23:599-606.

100 Egler J, Lang F: Triggering of Eryptosis, the Suicidal Erythrocyte Death, by Perifosine. Cell Physiol Biochem 2017;41:2534-2544. 


\section{Cellular Physiology Cell Physiol Biochem 2018;47:1259-1273 \begin{tabular}{lll} 
DOI: 10.1159/000490221 & and Biochemistry & $\begin{array}{l}\text { O } 2018 \text { The Author(s). Published by S. Karger AG, Basel } \\
\text { www.karger.com/cpb }\end{array}$ \\
\cline { 2 - 3 } & Published onnine; June 19, 2018
\end{tabular}}

Al Mamun Bhuyan/Lang: Afatinib-Induced Eryptosis

101 Abed M, Alzoubi K, Lang F, Al Mamun Bhuayn A: Stimulation of Phospholipid Scrambling of the Erythrocyte Membrane by 9-Cis-Retinoic Acid. Cell Physiol Biochem 2017;41:543-554.

102 Abed M, Thiel C, Towhid ST, Alzoubi K, Honisch S, Lang F, Konigsrainer A: Stimulation of Erythrocyte Cell Membrane Scrambling by C-Reactive Protein. Cell Physiol Biochem 2017;41:806-818.

103 Mischitelli M, Jemaaa M, Fezai M, Almasry M, Lang F, Faggio C: Stimulation of Erythrocyte Cell Membrane Scrambling by Adarotene. Cell Physiol Biochem 2017;41:519-529.

104 Al Mamun Bhuyan A, Nguyen MT, Bissinger R, Gotz F, Lang F: Lipopeptide-Induced Suicidal Erythrocyte Death Correlates with the Degree of Acylation. Cell Physiol Biochem 2017;41:296-309.

105 Al Mamun Bhuyan A, Wagner T, Cao H, Lang F: Triggering of Suicidal Erythrocyte Death by Gefitinib. Cell Physiol Biochem 2017;41:1697-1708.

106 Almasry M, Jemaa M, Mischitelli M, Lang F, Faggio C: Camalexin-Induced Cell Membrane Scrambling and Cell Shrinkage in Human Erythrocytes. Cell Physiol Biochem 2017;41:731-741.

107 Farag MR, Alagawany M, Tufarelli V: In vitro antioxidant activities of resveratrol, cinnamaldehyde and their synergistic effect against cyadox-induced cytotoxicity in rabbit erythrocytes. Drug Chem Toxicol 2017;40:196-205.

108 Al Mamun Bhuyan A, Nussle S, Cao H, Zhang S, Lang F: Simvastatin, a Novel Stimulator of Eryptosis, the Suicidal Erythrocyte Death. Cell Physiol Biochem 2017;43:492-506.

109 Al Mamun Bhuyan A, Cao H, Lang F: Triggering of Eryptosis, the Suicidal Erythrocyte Death by Mammalian Target of Rapamycin (mTOR) inhibitor Temsirolimus. Cell Physiol Biochem 2017;42:1575-1591.

110 Ghashghaeinia M, Wesseling MC, Ramos E, Petkova-Kirova P, Waibel S, Lang E, Bissinger R, Alzoubi K, Edelmann B, Hosseinzadeh Z, Dreischer P, Shahvaroughi-Farahani A, Mrowietz U, Koberle M, Kaestner L, Bernhardt I, Martinez-Ruiz A, Wieder T, Lang F: Trifluoperazine-Induced Suicidal Erythrocyte Death and S-Nitrosylation Inhibition, Reversed by the Nitric Oxide Donor Sodium Nitroprusside. Cell Physiol Biochem 2017;42:1985-1998.

111 Al Mamun Bhuyan A, Signoretto E, Bissinger R, Lang F: Stimulation of Suicidal Erythrocyte Death by Ceritinib-Treatment of Human Erythrocytes. Cell Physiol Biochem 2016;40:1129-1140.

112 Jemaa M, Mischitelli M, Fezai M, Almasry M, Faggio C, Lang F: Stimulation of Suicidal Erythrocyte Death by the CDC25 Inhibitor NSC-95397. Cell Physiol Biochem 2016;40:597-607.

113 Jemaa M, Fezai M, Lang F: Inhibition of Suicidal Erythrocyte Death by Reversine. Cell Physiol Biochem 2017;41:2363-2373.

114 Al Mamun Bhuyan A, Bissinger R, Cao H, Lang F: Inhibition of Erythrocyte Cell Membrane Scrambling by ASP3026. Cell Physiol Biochem 2017;43:507-517.

115 Al Mamun Bhuyan A, Ashiqul Haque AKM, Sahu I, Cao H, Kormann MSD, Lang F: Inhibition of Suicidal Erythrocyte Death by Volasertib. Cell Physiol Biochem 2017;43:1472-1486.

-116 Jagadish S, Hemshekhar M, NaveenKumar SK, Sharath Kumar KS, Sundaram MS, Basappa, Girish KS, Rangappa KS: Novel oxolane derivative DMTD mitigates high glucose-induced erythrocyte apoptosis by regulating oxidative stress. Toxicol Appl Pharmacol 2017;334:167-179.

-117 Lang E, Jilani K, Bissinger R, Rexhepaj R, Zelenak C, Lupescu A, Lang F, Qadri SM: Vitamin D-Rich Diet in Mice Modulates Erythrocyte Survival. Kidney Blood Press Res 2015;40:403-412.

118 Abed M, Artunc F, Alzoubi K, Honisch S, Baumann D, Foller M, Lang F: Suicidal erythrocyte death in endstage renal disease. J Mol Med (Berl) 2014;92:871-879.

119 Polak-Jonkisz D, Purzyc L: Ca(2+) influx versus efflux during eryptosis in uremic erythrocytes. Blood Purif 2012;34:209-210; author reply 210.

$\checkmark 120$ Calderon-Salinas JV, Munoz-Reyes EG, Guerrero-Romero JF, Rodriguez-Moran M, Bracho-Riquelme RL, Carrera-Gracia MA, Quintanar-Escorza MA: Eryptosis and oxidative damage in type 2 diabetic mellitus patients with chronic kidney disease. Mol Cell Biochem 2011;357:171-179.

121 Bissinger R, Artunc F, Qadri SM, Lang F: Reduced Erythrocyte Survival in Uremic Patients Under Hemodialysis or Peritoneal Dialysis. Kidney Blood Press Res 2016;41:966-977.

122 Meyring-Wosten A, Kuntsevich V, Campos I, Williams S, Ma J, Patel S, Ornillo C, Thijssen S, Kotanko P: Erythrocyte Sodium Sensitivity and Eryptosis in Chronic Hemodialysis Patients. Kidney Blood Press Res 2017;42:314-326.

123 Lang F, Bissinger R, Abed M, Artunc F: Eryptosis - the Neglected Cause of Anemia in End Stage Renal Disease. Kidney Blood Press Res 2017;42:749-760. 


\section{Cellular Physiology Cell Physiol Biochem 2018;47:1259-1273 \begin{tabular}{l|l} 
DOI: 10.1159/000490221 & $\begin{array}{l}\text { O 2018 The Author(s). Published by S. Karger AG, Basel } \\
\text { www.karger.com/cpb }\end{array}$ \\
\hline
\end{tabular}}

Al Mamun Bhuyan/Lang: Afatinib-Induced Eryptosis

-124 Lang PA, Beringer O, Nicolay JP, Amon O, Kempe DS, Hermle T, Attanasio P, Akel A, Schafer R, Friedrich B, Risler T, Baur M, Olbricht CJ, Zimmerhackl LB, Zipfel PF, Wieder T, Lang F: Suicidal death of erythrocytes in recurrent hemolytic uremic syndrome. J Mol Med (Berl) 2006;84:378-388.

125 Bartolmas T, Mayer B, Balola AH, Salama A: Eryptosis in autoimmune haemolytic anaemia. Eur J Haematol 2018;100:36-44.

126 Nicolay JP, Schneider J, Niemoeller OM, Artunc F, Portero-Otin M, Haik G, Jr., Thornalley PJ, Schleicher E, Wieder T, Lang F: Stimulation of suicidal erythrocyte death by methylglyoxal. Cell Physiol Biochem 2006;18:223-232.

127 Pinzon-Diaz CE, Calderon-Salinas JV, Rosas-Flores MM, Hernandez G, Lopez-Betancourt A, QuintanarEscorza MA: Eryptosis and oxidative damage in hypertensive and dyslipidemic patients. Mol Cell Biochem 2018;440:105-113.

-128 Lang E, Gatidis S, Freise NF, Bock H, Kubitz R, Lauermann C, Orth HM, Klindt C, Schuier M, Keitel V, Reich M, Liu G, Schmidt S, Xu HC, Qadri SM, Herebian D, Pandyra AA, Mayatepek E, Gulbins E, Lang F, Haussinger D, Lang KS, Foller M, Lang PA: Conjugated bilirubin triggers anemia by inducing erythrocyte death. Hepatology 2015;61:275-284.

129 Bissinger R, Schumacher C, Qadri SM, Honisch S, Malik A, Gotz F, Kopp HG, Lang F: Enhanced eryptosis contributes to anemia in lung cancer patients. Oncotarget 2016;7:14002-14014.

130 Qadri SM, Mahmud H, Lang E, Gu S, Bobbala D, Zelenak C, Jilani K, Siegfried A, Foller M, Lang F: Enhanced suicidal erythrocyte death in mice carrying a loss-of-function mutation of the adenomatous polyposis coli gene. J Cell Mol Med 2012;16:1085-1093.

131 Lang E, Bissinger R, Qadri SM, Lang F: Suicidal death of erythrocytes in cancer and its chemotherapy: A potential target in the treatment of tumor-associated anemia. Int J Cancer 2017;141:1522-1528.

132 Bissinger R, Kempe-Teufel DS, Honisch S, Qadri SM, Randrianarisoa E, Haring HU, Henes J, Lang F: Stimulated Suicidal Erythrocyte Death in Arteritis. Cell Physiol Biochem 2016;39:1068-1077.

133 Jiang P, Bian M, Ma W, Liu C, Yang P, Zhu B, Xu Y, Zheng M, Qiao J, Shuai Z, Zhou X, Huang D: Eryptosis as an Underlying Mechanism in Systemic Lupus Erythematosus-Related Anemia. Cell Physiol Biochem 2016;40:1391-1400.

134 Lang PA, Schenck M, Nicolay JP, Becker JU, Kempe DS, Lupescu A, Koka S, Eisele K, Klarl BA, Rubben H, Schmid KW, Mann K, Hildenbrand S, Hefter H, Huber SM, Wieder T, Erhardt A, Haussinger D, Gulbins E, Lang F: Liver cell death and anemia in Wilson disease involve acid sphingomyelinase and ceramide. Nat Med 2007;13:164-170.

135 Zhong H, Wake H, Liu K, Gao Y, Teshigawara K, Sakaguchi M, Mori S, Nishibori M: Effects of Histidine-rich glycoprotein on erythrocyte aggregation and hemolysis: Implications for a role under septic conditions. J Pharmacol Sci 2018;136:97-106.

136 Fallatah 0, Georges E: Apigenin-induced ABCC1-mediated efflux of glutathione from mature erythrocytes inhibits the proliferation of Plasmodium falciparum. Int J Antimicrob Agents 2017;50:673-677.

137 Totino PR, Lopes SC: Insights into the Cytoadherence Phenomenon of Plasmodium vivax: The Putative Role of Phosphatidylserine. Front Immunol 2017;8:1148.

138 Lang E, Zelenak C, Eberhard M, Bissinger R, Rotte A, Ghashghaeinia M, Lupescu A, Lang F, Qadri SM: Impact of cyclin-dependent kinase CDK4 inhibition on eryptosis. Cell Physiol Biochem 2015;37:1178-1186.

139 Liu DH, Yao YT, Li LH, Huang CM: Effects of Ulinastatin on In Vitro Storage Lesions of Human Red Blood Cells. Clin Lab 2017;63:833-838.

140 Rodolfo B, Serafina P, Giuseppe B: Mechanisms Involved in the Increased Hemolysis in the Fetus and Newborn. Curr Pediatr Rev 2017;13:188-192.

141 Jemaa M, Fezai M, Bissinger R, Lang F: Methods Employed in Cytofluorometric Assessment of Eryptosis, the Suicidal Erythrocyte Death. Cell Physiol Biochem 2017;43:431-444.

142 Andrews DA, Low PS: Role of red blood cells in thrombosis. Curr Opin Hematol 1999;6:76-82.

143 Closse C, Dachary-Prigent J, Boisseau MR: Phosphatidylserine-related adhesion of human erythrocytes to vascular endothelium. Br J Haematol 1999;107:300-302.

144 Gallagher PG, Chang SH, Rettig MP, Neely JE, Hillery CA, Smith BD, Low PS: Altered erythrocyte endothelial adherence and membrane phospholipid asymmetry in hereditary hydrocytosis. Blood 2003;101:46254627. 


\section{Cellular Physiology Cell Physiol Biochem 2018;47:1259-1273

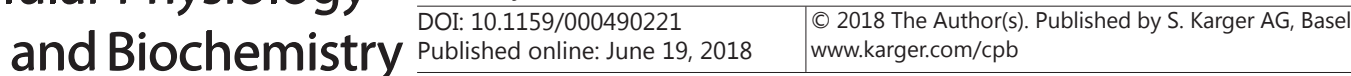

Al Mamun Bhuyan/Lang: Afatinib-Induced Eryptosis

145 Pandolfi A, Di Pietro N, Sirolli V, Giardinelli A, Di Silvestre S, Amoroso L, Di Tomo P, Capani F, Consoli A, Bonomini M: Mechanisms of uremic erythrocyte-induced adhesion of human monocytes to cultured endothelial cells. J Cell Physiol 2007;213:699-709.

146 Wood BL, Gibson DF, Tait JF: Increased erythrocyte phosphatidylserine exposure in sickle cell disease: flowcytometric measurement and clinical associations. Blood 1996;88:1873-1880.

147 Borst O, Abed M, Alesutan I, Towhid ST, Qadri SM, Foller M, Gawaz M, Lang F: Dynamic adhesion of eryptotic erythrocytes to endothelial cells via CXCL16/SR-PSOX. Am J Physiol Cell Physiol 2012;302:C644-C651.

148 Chung SM, Bae ON, Lim KM, Noh JY, Lee MY, Jung YS, Chung JH: Lysophosphatidic acid induces thrombogenic activity through phosphatidylserine exposure and procoagulant microvesicle generation in human erythrocytes. Arterioscler Thromb Vasc Biol 2007;27:414-421.

149 Zwaal RF, Comfurius P, Bevers EM: Surface exposure of phosphatidylserine in pathological cells. Cell Mol Life Sci 2005;62:971-988.

150 Harrison HE, Bunting H, Ordway NK, Albrink WS: The Pathogenesis of the Renal Injury Produced in the Dog by Hemoglobin or Methemoglobin. J Exp Med 1947;86:339-356. 